\title{
Transboundary Animal Diseases and International Trade
}

\author{
Andrés Cartín-Rojas
}

Additional information is available at the end of the chapter

http://dx.doi.org/10.5772/48151

\section{Introduction}

Currently, livestock sector accounts for nearly half of global agricultural economy. Recent animal health emergencies have highlighted the vulnerability of pecuary industry to epizootic episodes caused by infectious diseases. The impact of animal diseases on health and human welfare is being increasingly considered. Sixty percent of emerging diseases that affect humans are zoonoses, most of them (about 75\%) originate from wildlife. Many of those diseases are common to productive domestic animals, due to the multiple interrelationships and the ability of many microorganisms to mutate and to colonize new hosts. Therefore, direct impact of Transboundary Animal Diseases in agriculture and public health, constitute a serious limitation to export living animals and their products, as well for international trade. Moreover, seriously compromised food security and causing a high socioeconomic impact on agricultural exporting nations.

During the next 15 to 20 years, the demand for livestock products is considering to double, a process called "Livestock Revolution" driven by changing a cereal-based diet to a diet based on proteins. It is estimated that in $2015,60 \%$ of meat and $52 \%$ of the milk, will be consumed in developing countries [27]. The increasing globalization markets, facilitates the introduction of transboundary animal disease. Trade in agricultural products is increasingly accepted as an important factor in the strategy to mitigate and reduce poverty. This indicates that developing countries also need more support and sustained efforts to achieve fully integrated within the animal health standards and food safety, since progress in these areas are bound to have a beneficial impact, not only in the ability to participate in foreign trade but also trade locally, allowing integrative markets in the poorest communities. However, is essential to generate a concerted effort to be meeting the basic elements of the Agreement on Sanitary and Phytosanitary. Therefore, recognized international organizations such as FAO, OIE, WTO and WHO recognize the need to change veterinarian's traditional view and 
focusing animal health services on the early epidemiological investigation and prevention of zoonoses through a holistic and transdiciplinary joint initiative called the "One Health".

In this conceptual chapter, topics on emerging and zoonotic diseases origin and dynamics, the importance of transboundary animal diseases for international trade of livestock commodities and possible future solutions among medical and biological disciplines is developed by reviewing relevant literatures, analyzing and exemplifying applicable case studies, identifying current trends and discussing the potential impact on developing and growth of countries' economies. With few studies in this particular area, the author adopts an inductive approach, designed to generate new understanding and propositions for further research.

\section{Origins and catalysts of zoonoses and emerging diseases}

Food and Agriculture Organization of the United Nations, defines Transboundary Animal Diseases (TADs) as: "Those diseases with an essential impact on the economy, trade and/or food security of a group of countries, which can be easily spread to other countries, reaching epidemic proportions and that require control and eradication cooperation between different nations" [32].

There are two major types of TADs with an economic impact on international trade: emerging diseases and zoonoses. The World Organization for Animal Health (OIE) defines emerging diseases as: "Those that are able to expand its epidemiological spectrum, appearing in a not endemic geographic area, affecting new susceptible species; or referring to a completely unknown pathogen which is detected for the first time". Zoonoses are: "Any diseases or infections which are naturally transmissible from animals to humans" [69]. Zoonotic infections, according to its cycle can be classified as synanthropic when they have an urban cycle or exoanthropic when the cycle is sylvatic [23]. When a zoonotic disease is not well addressed by national or international public or animal health services is known as neglected zoonoses. Newly emerging diseases such as avian influenza, Nipah virus or variants in prionic diseases, also have showed the potential of the domestic productive animals-humans-wildlife interface to develop and transmit new infectious agents.

The human-animal interface is fluid and our interaction with other species, varies in response to anthropogenic factors that favor the potential for transmission of zoonotic agents $[12,77]$. For instance, this is extremely important for two pragmatic issues:

1. Pests and animal diseases cause the annual loss of more than $40 \%$ in the global food supply [33], causing a direct impact in the agricultural sector, compromising seriously food security, constraint on international trade and export of living animals and their products, and causing an annual high economic impact on agricultural exporting nations.

2. TADs also have an important effect on public health. The disability-adjusted life years $(D A L Y s)$ is a measure of overall disease burden, expressed as the number of years lost due to ill-health, disability or early death [3]. Infectious diseases also lead to compromised health and disability, accounting for nearly $30 \%$ of all DALYs worldwide 
[36]. Therefore, they contribute to increase the burden of diseases and the subsequent economic loss to governments, due to the associate cost of dead, hospitalization and inabilities. Nowadays it is estimated that about $60 \%$ of currently known infectious diseases affecting humans are zoonoses. Nearly three-quarters of them are diseases which have a wild reservoir $[22,54]$.

Thus, emerging and zoonotic diseases characterizes by having natural nidality (a term proposed by the Russian parasitologist E. N. Pavlosvky in 1939), that means: "The ability to maintain a dynamic focus and a permanent movement of a pathogen in a wild animal population within a geographic location, contributing to maintain a zoonotic pool" [43]. According to this theory, humans can acquire diseases (zoonoses or emerging diseases) or transmit diseases to susceptible animal populations (antropozoonoses) when the natural balance of the ecological nidus of a particular disease is disrupted. Consequently, any change or alteration affecting the ecology, distribution and abundance of its reservoirs/vectors, significantly alter the disease epidemiology [4]. Most disruptors that alter the dynamic equilibrium and favor the emergence of new pathogens are anthropogenic [24, 74]. In other words, disease emergence is actually a temporal and spatial evolutionary response to different environmental changes caused by humans [39], which has a dual component: a) first, is necessary a colonization and adaptation of a pathogen to its new host (initially the number of pathogens decrease reaching extinction, but some organisms will survive and increase their virulence), this process is called microbial traffic, b) the subsequent spread of the pathogen within the new susceptible population (greatly favored by anthropogenic changes) [84]. Therefore, TADs have a multicasual origin; some factors associated with this process include: a) Trade and international travel (increased frequency and speed of local and international travel, fostered by the globalization process promotes the spread of microorganisms on a global scale), b) Changes agricultural practices (animal domestication was one of the main promoters of microbial evolution by facilitating the availability of new susceptible hosts at high densities, due to the intensification of livestock systems), c) Climate change (which causes changes eco-geographical distribution of vectors), d) Reduction of habitat and increased contact with wild vectors/ reservoirs, and h) Introduction of naïve wild and domestic animals to new geographic areas where the disease is endemic and immunologically unknown for them (increases zoonotic pool within a geographic region) $[13,19,26]$.

\section{Wildlife and their importance on international trade of livestock's products}

The term global express is defined as: "The volumes of goods moving globally" [12]. The globalization of markets has contributed to the continually increasing of the gross domestic product (GDP, a modality for measuring economies and development of nations) in the last two decades. Thus, international trade of livestock products has become an important part of the world economy. Therefore, the current economic trend around market globalization by TADs, the increase in human population and the subsequent increase in food demand 
(mainly in developing countries), the evolution of pathogens and changes in the distribution of vectors as a direct result of climate change, seems to be the biggest challenges in the coming years to the national public and animal health systems, in terms of animal disease control and prevention of emerging zoonoses $[66,90]$.

Estimating that human population will increase from nearly 7 billion in 2010 to about 9.5 billion in 2050, food supply will increase too with a consequent continually rising social and environmental pressures. For example, it is estimated that by $2015,60 \%$ of meat and $52 \%$ of milk will be consumed in developing countries [32]. Since the 1960's global meat production has more than tripled, milk production has doubled, and egg production has almost fourfold [89]. Global production and consumption of livestock products will likely continue to rise. In Latin America meat productions represented in the 1990 decade, 30\% of the entire world production and $22.7 \%$ of the exported commodities. Poultry industry grew $8 \%$ in Central America with an annual growth rate of $14 \%$. The participation of agricultural exports in gross domestic product in Central America represented 9.7\%, 4.8\% in the Caribbean region and $2.7 \%$ in South America [101]. Interestingly, although developing countries contribute with a large percentage of livestock production and raw materials used in food industry, developed countries that account for only $20 \%$ richest in the world; consumes $86 \%$ of all goods and services in the world. Instead, the poorest countries in the world (mostly located in Africa, with the exception of one (Haiti) located in the Latin American region), ingest only $1.3 \%$ of all food world production [102].

Infectious diseases share a common pathophysiology between domestic and wildlife animals. These diseases are not only one of the largest sources of non-tariff barriers to international trade. But also, they affect the dynamism and fluidity of the agronomic input markets, either by creating higher costs of production in industries directly dependent on these inputs, or generating commercial levies to the export country on certain animal products as a direct consequence of a disease epidemic, generating an increase in the complexity of the patterns of consumption and access to competitive global markets. Additionally, are the monumental annual costs that several countries worldwide spend on control and eradication programs of TADs, as well as, the resilient and compensatory payments by governments to livestock sector after a disease outbreak [98]. The Organization of the United Nations Food and Agriculture Organization (FAO), pests and animal diseases cause the loss of more than $40 \%$ in the global food supply, being a clear threat to the residual economies of developing countries and food security of its inhabitants [35]. In general livestock's products have increased their international trade in $4 \%$ only in the last two decades [62]. However, as a result of the emergence and re-emergence of various animal diseases, such as bovine spongiform encephalopathy (BSE), the annual growth of meat products decreased $2 \%$ in the late 1990s [63]. Therefore, the cost of transboundary animal diseases relates to agricultural products, to the country's economy and international markets are monumental. Thus, it is very important to create public policies focused to assure countries' food security (especially in developing nations) to avoid negative economic impacts caused by TADs, especially on the more susceptible social stratus. 
The World Bank has estimated that zoonotic disease outbreaks in the past 10 years have cost worldwide more than \$US200 billion due to loss of trade, tourism and tax revenues [67]. For example, the outbreak on Newcasttle virus in Australia on 1999 costs on trade and export losses was about $\$ 15$ million [40]. The economic costs of the hog cholera epizooty in the Netherlands in 1997-1998 will approach \$US 130 million. The eradication cost of African Swine Fever only in the US on 2000 was calculating on approximately \$US 16.2 million [46].

In Canada, the outbreak of BSE detected in 2003 represented a loss of \$US 333 million to its livestock industry, imposed a commercial blockade on Canadian beef purchases and generating a decrease of $25 \%$ in their meat metric annual tons produced and exported to United States, the main destination market. Later, United States faced a similar problem when there was an outbreak on December 2003. The first reaction of the international meat market was the immediate suspension of U.S. beef purchases, causing a loss of over 2,600 million dollars and a fall of $18 \%$ in the American beef commodities export volume only in 2004. Similarly, commercial losses to Argentina and Uruguay, as a result of the same disease were estimated at \$US 400 million and \$US 150 million, respectively. While the value of trade losses for the english meat industry due to BSE was egregious (\$US 9.2 billion) [102].

The 1993 Food and Mouth Disease (FMD) outbreak in Italy cost was estimated at \$US 120 million. Similarly, FMD diagnosed in Taiwan on 1997 costs approximately \$US 15 billion. The outbreak of FMD in China produced a decrease of \$US 1600 to 234 million on 1996-1997 in their international market [63]. Average expected annual losses due to FMD epidemics in the Netherlands were also calculated on approximately US\$15 million [47]. The FMD outbreak in Korea in 2000 ended its trade with Japan, with an approximate cost of \$US 300 million, enabling other exporting countries increase their participation in the Japanese market. The extreme interrelation and importance among wildlife, international trade and agricultural economy of developing countries will be widely exposed with two case studies focused on the ecoepidemiology of some emerging and zoonotic viruses.

\subsection{Case study I: Orthomyxoviruses and wild birds}

There are several strains types of avian influenza virus, belonging to the Orthomyxovirus genus and commonly isolated from aquatic birds, mainly orders Anseriformes and Charadriiformes. In addition, the highest ecoepidemiological prevalence is observed on migrating birds who feed on the water surface [7]. This is particularly important for Costa Rica, where more than $60 \%$ of reported bird species are migratory, found in the wetlands of some important national parks (Tortuguero, Palo Verde, Isla del Coco and Caño Negro), which are important wintering sites to stop during migration season, working as nesting shelters [78]. Various studies show the transmission of the influenza virus among wild and domestic birds [15].

The avian influenza virus has managed to avoid animal health barriers imposed by various international territories, expanding by more than 45 countries and causing over 100 deaths, seriously affecting the global poultry system productivity, and also generating to national 
health services an economic burden associated with a reduction of the workforce; product of death and direct side effects of the disease.

In commercial terms, it is estimated that more than \$US200 million animals have died or been slaughtered only in Asia, where economic losses in the poultry sector are estimated in more than \$US10 billion. Added to this, uncertainty about the disease spread have created a widespread fear that affects all markets and consumers, caused a decline in poultry marked consumption, and the imposition of sanitary restrictions to poultry commodities. These events led to a decrease of $8 \%$ in the international poultry trade in 2004 . Nowadays, the American continent has the two biggest exporters worldwide (Brazil and USA) for poultry products. In this scenario, preventive measures become urgent, especially when you consider that the restoration of trade flow is slow, due to international trade embargoes which countries are subjected [86]. For example, the United Arab Emirates (UAE) is one of the largest importers of poultry products worldwide. In 2004 this country was the seventh largest importer of Brazilian products, corresponding to 122,000 metric tons or $4.6 \%$ of total exports for that country. South Africa is also one of the main consumer markets for poultry products in Brazil and is the largest importer in Africa. This country was the sixth largest importer in 2004, corresponding to $6 \%$ of the volume of poultry products exported by Brazil in that year. In this context, in the case of an avian flu spread in the Americas its represent a reduction of more than 270,000 metric tons to Brazilian goods [85].

It is estimate that the Latin American poultry industry, representing about $12.7 \%$ of all livestock in the region, produces 14 million metric tons of meat and 5 million metric tons of eggs annually [75]. In addition, the sector employs $0.88 \%$ of the economically active population in the continent. Therefore, the budget needed by Latin American countries for a possible outbreak of Avian Influenza is \$US274 million, of which \$US148 million would be to coordinate prevention and surveillance, \$US72 million for animal vaccination and \$US 54 million used as a compensation fund. The authors estimate that the cost of a pandemic to Latin America ranges between 1\% $-5 \%$ of GDP across the region. Meanwhile, it is estimated that the number of deaths range between 45,000 to 2.2 million people. Currently, is estimated that the economic impact of pandemic avian flu is over \$US300 billion worldwide [2]. Therefore ecoepidemiological studies of disease in wild birds in developing nations, by the national public animal health services are of utmost importance for anticipation, monitoring, prevention and preparedness for possible disease outbreaks.

\subsection{Case study II: Paramyxovirus and fruit bats}

Nipah virus is a neurotropic paramyxovirus first recognized in Malaysia during 1998-1999. Subsequent epidemiological studies demonstrated that fruit bats (genus Pteropus sp.), are natural reservoirs and swines acts as amplifiers for humans. The large-scale deforestation occurred in Malaysia and Sumatra together with a large climatic oscillations of the phenomenon of El Niño, a widespread drought during the year 1997 that altered bat migration routes and feeding behavior producing a greater association between bats and pigs, are the main ecological disruptors associated to facilitating for the first time the 
introduction of this virus in Malaysian pig farms. Added to this, pig farms size and intensive management techniques (high turnover of piglets) allowed the virus to circulate within the population, and subsequently infect humans working with them [70].

The outcome of this outbreak can be viewed from two different angles. In terms of public health, a total of 265 cases of viral encephalitis led to 105 human deaths. However, the major implication of this emerging disease was its direct impact on Malaysian goods and livestock trade. For example, to prevent the spread of the outbreak, the local government closed 896 pig farms. The cost was estimated at \$US58.3 million for the slaughter of approximately 1.1 million animals and the subsequent financial compensation to pig producers [29]. In addition, the government spent another \$US136 million to implement sanitary control programs. Malaysia also lost \$US120 million dollars as a direct consequence in the fall of its international markets, \$US124 million associated with the pig farmer's financial losses due to a decrease in $80 \%$ consumption of pork products by the international public [38]. The Nipah virus outbreak also had a direct impact on the country's workforce with a huge social cost affecting over 12.000 people working on pig farms and related industries [55]. For example, most swine farms changed their business approach to focus on dairy or bovine beef production and many pig farmers are also now employed in palm plantations, where working conditions are not very optimistic [30]. In addition, as Malaysian's livestock sector was markedly decreased, fat and oils industry derived from these animals also suffered losses for \$US35 million and other agricultural industries such as production of palm, coconut and tea also suffered an indirect impact due to these crops constitutes an important part of Pteropus bat's natural diet. Finally, after the outbreak of Nipah virus, pork consumption was reduced by approximately 30\% and Singapore (previously the largest importer of pork meat products and breeding stock from Malaysia), banned all imports from this country on 1999. The total cost of national economic damage was estimated at approximately \$US541 million [30, 93].

Costa Rica has currently over 110 species of bats reported [56]. Despite that the presence of Nipah virus has been found mainly in the genus Pteropus sp., located only in Asia and Africa, scientific reports have identified the presence of antibodies against the virus in insectivorous bats of genus Myotis spp [57], of which there are 6 species already reported for Costa Rica (it is thought that some bat viruses have been co-evolve and coexist with them for thousands of years). The discovery of new Paramyxovirus and Artrovirus [105-106] (which are capable of avoiding the species barrier, but its zoonotic potential remains unknown) remarks the importance of studies ecoepidemiological in neotropical bats, as well as for others wildlife reservoirs of important etiologic agents that can generate a high economic negative impact to the livestock sector, through trade barriers imposition and possible future infectious to humans.

\section{Wildlife diseases monitoring systems and their importance for international trade}

Avoiding closure of a country commercial borders by the national veterinary services, is accomplish by having an adequate, robust and effective monitoring system, that integrate 
not only the veterinary practice in the field, but also involving and integrating national public health system and private productive sector with the accredited international bodies' normative. Monitoring systems should base their functionality on the scope of the same system, by studying or evaluating not only traditional animal diseases, but also reporting significant epidemiological events related to neglected zoonoses and emerging diseases; integrating a holistic component based on the ecological understanding of disease dynamics, its transmission routes/sources and its economic impact on the international trade $[8,94]$. TADs are a continuous ecological process difficult to eradicate, whose main deficiency lies not in the scarcity of control means, but in the failure of public policies that involves all stakeholders.

Adequate national and international legislation, must focused on actively combat the deliberate or accidental introduction of pathogens and pests to protect the agriculture of the harmful effects of bioterrorism; renounce the mass slaughter as a method of struggle, make the appropriate investments in technology and science within the country to produce shared efforts to facilitate adequate preparation for the government and private sector working together in a process whose costs bear the economic and social impact caused by different diseases; allowing the application of an effective system of surveillance, diagnosis and first response must be applied [11].

There is also a decrease in the infrastructure of health services worldwide. There is also an urgent need to rebuild and expand scientific knowledge and skills in new areas of human and veterinary medicine by integrating them within a global context of health, in which human, animal and ecosystem health are intrinsically linked. According to Brown (2004) [11], "Despite the twin threats of agroterrorism and emerging diseases ... there is a sharp decline in the number of veterinarians and other health professionals at government level, compared to existing emergency". Veterinary public health must resurgence, aimed to promoting control and eradication of zoonoses, especially in developing countries that relies its economy in a resilient economic system. Therefore, it is vital to increase the scope of the veterinarian role by generating and stimulating incentives and public policies aimed to controlling transboundary animal diseases and supporting the economy and world trade of livestock inputs $[42,96]$.

The decision to close the borders to trade when a neighbor country detects a transboundary disease does not appear to be the most appropriate measure for three main reasons:

1. Constitutes a transgression to international law,

2. Causes undue financial loss to other exporter regions within the injury country, that is not affected by the disease and,

3. Because it weakens the enforcement or international normative when an opposite situation is given, since no country is completely safe from pests and diseases due to intense the current trade flows.

Historically, most research efforts of zoonoses and emerging diseases have been focused on human domestic animal species and pecuary production systems, translating 
biosecurity as a risk analyses concept focused essentially on bio-economic consequences of biological hazards introduction [22, 76]. The competent international body which harmonizes and equates such sanitary measures worldwide in this area is the World Organization for Animal Health (OIE). The OIE is an intergovernmental organization created by an international convention on January 25, 1924, signed by 28 countries. In May 2004, the OIE totaled 167 Member Countries. Its headquarters is in Paris, France.

The main functions of the World Organization for Animal Health, include: i) Ensure transparency of the animal health situation in the world, ii) Collection, analysis and dissemination of veterinary scientific information, iii) Offer technical assistance and encourage international solidarity to promote the control and eradication of diseases, iv) Protect the safety of international trade in animals and animal products by harmonized sanitary guidelines and recognized by the World Trade Organization, under the mandate of the OIE in the Agreement on the Application of Sanitary and Phytosanitary Measures (SPS Agreement), v) Improving the legal framework and resources of veterinary services, and vi) To ensure better food safety of animal and improve animal welfare by using science-based. In fact, OIE is accepted as the reference standard organization for SPS Agreement on animal health and zoonoses (SPS Agreement Art. 3, and annex A paragraph 3-b) [41]. These tasks are achieved through various activities, including the establishment of normative standards, guidelines and recommendations in the field of animal health and its products. The OIE also maintains a list of mandatory reporting diseases of economic importance and the World Animal Health Information System (WAHIS), an internet-based computer system that processes data on animal diseases worldwide in real-time and then informs the international community constituting an early epidemiological warning system [97]. WAHIS has a juridical validation for all OIE members and since 2009 wildlife diseases online notification system have been ongoing.

In 2005, the OIE's Terrestrial Code introduced the term of compartmentalization or regionalization, a concept that subsequently has been included on its new versions (for more information, please see chapter 4.3, OIE Terrestrial Animal Health Code 2011). This designation also contained in the SPS Agreement has been of great importance for world trade, as it allows flexible trade restrictions arising from the presence of animal diseases. Thus, countries or a group of them may have the opportunity to export from areas that have demonstrated to be free of a particular disease or pest or where disease prevalence is low, even when the disease existed elsewhere in the country/region [14]. Therefore, the International Animal Health Code published by the OIE establish the methodology for quantitative risk analysis associated with trade in living animals and its products, through assessing a potential partner for trade avoiding the imposition of tariff barriers. This method applies in principle to standardize procedures for all countries. However, this does not erase the reality that for some countries the use of these procedures is extremely expensive. Thus, the fundamental importance of regionalization for agricultural exporting 
countries, efforts in the meetings of the WTO-SPS Agreement should focus on the major challenges:

1. Definition of agency will be responsible for issuing the guidelines containing explicit provisions on the procedures that countries must apply for recognition of disease in other countries and effective enforcement the subsequent incorporation of these guidelines in national legal systems of the members,

2. Promotion of programs of cooperation among members, especially between neighboring countries, for cases in which adjustments are required regulatory or technical training,

3. Provision in international standards of a simpler procedure that allows automatically receives recognition of disease free zone made by international organizations.

Today, it is widely recognized that those countries implementing ecoepidemiologic monitoring programs in wildlife possess significant advantages in the fight against TADs, such as:

1. Improved scientific basis for understanding the epidemiology of certain animal diseases and zoonoses that can have a profound economic and health impact on public health and animal health,

2. Detect the presence of key pathogens, especially those cited in the list of mandatory reporting of the World Organization for Animal Health (OIE), which can seriously compromise the perception of "country's disease free status" that a nation possesses,

3. Monitoring programs in wildlife are serving as strategies aimed at integration, both supporting and strengthening the national infrastructure for animal health, and their respective programs preventive epidemiological,

4. Allow for early detection and early emerging and exotic agents with potential economic impact on the livestock sector and international trade of a country [43, 65].

5. Allow the detection, prevention and control of etiologic agents that may reach seriously compromise a country's public health, causing high mortality/morbidity, and

6. Wildlife often serves as a sentinel of various pathogens, enabling effective management and control of diseases in domestic animals.

In Africa, the Wildlife Conservation Society (WCS), OIE, WHO and other NGOs worldwide as IUCM (The World Conservation Union) and WWF (World Wildife Foundation), among others, implement a joint initiative called AHEAD (Animal Health for the Environment and Development), which conducts research on transboundary animal diseases at the interfacewildlife-human-productive domestic animals in various African nations including Kenya, Zimbabwe, Tanzania, Uganda, Zambia, Namibia, South Africa, Botswana and Mozambique [72]. Another successful examples of wildlife disease monitoring systems are: National Wildlife Disease Program (NWDP) in the Unites States, Canadian Cooperative Wildlife Health Center in Canada (CCWHC), the Instituto de Investigación en Recursos Cinegéticos (IREC) in Spain, and the Réseau National de Surveillance Sanitaire de la Faune Sauvage (SAGIR) in France-Martinique Island. 


\section{The one health concept: An holistic, integrative and transdisciplinary paradigm for controlling, preventing and monitoring TADs}

The term zoonosis was proposed in 1855 by the German scientist Robert Virchow [17]. Virchow was also the first to propose the term one health, emphasizing the importance and interrelationship between human and veterinary medicine for diseases prevention, study and control [71]. Subsequently, the one health concept was internationally distributed by Calvin Schwabe [43] and William Osler [51].

The OIE's strategic plan for the period 2011-2015, seeks to ensure transparency in communication and global spread of animal diseases. One of the primary concepts of the operational plan is to create forums and opportunities for a global strategy for risk management in the interface-wildlife-human-domestic productive animals, and to mitigate the impact of climate change on the distribution and epidemiology of TADs and livestock production systems.

Under the premise that international animal health is a public good, in the last 8 years the term one health has reemerged as an innovate solution to combat TADs. The European Union adopted the following definition for One Health approach: "The improvement of health and well-being through (i) the prevention of risks and the mitigation of effects of crises that originate at the interface between humans, animals and their various environments, and (ii) promoting a crosssectoral, collaborative, "whole of society" approach to health hazards, as a systemic change of perspective in the management of risks" [67]. Additionally, the Executive Summary of the American Veterinary Medical Association (AVMA) One Health Initiative Task Force (OHITF), describes One Health as: "The integrative effort of multiple disciplines working locally, nationally, and globally to attain optimal health for people, animals, and the environment" [53].

The one health concept also matches with Conservation Medicine (CM), an emerging veterinary medical discipline. CM links human and animal health within an ecological context, studying the effects of emerging diseases in terrestrial vertebrates and their impact on human health, animal health and direct impact on species conservation [91].

Nowadays, many countries around the world have adopted the initiative One Health initiative, due to the fundamental bases of all health and scientific effort begins with education and collaborative research. Likewise, many internationally renowned organizations such as American Medical Association, American Veterinary Medical Association, Center for Disease Control and Prevention, American Association of Tropical Medicine, World Health Organization, Food and Agriculture Organization, United States Geological Survey National Wildlife Health Center, United States Department of Agriculture, Canadian Cooperative Wildlife Health Center, Laboratoire Nationale de Sante Post of Republic of Congo Brazzaville, IUCN Commission on Environmental Law, Wildlife Trust, The Consortium for Conservation Medicine, and the Wildlife Conservation Society have now taken the initiative and promote this movement [71].For more information please visit: http://www.onehealthinitiative.com. Similarly, the joint strategic framework for reducing risks of infectious diseases at the interface-ecosystems-human-livestock from 
United Nations Children's Fund (UNICEF), in conjunction with the World Bank (WB), Organization of the United Nations Food and Agriculture Organization (FAO), World Organization for Animal Health (OIE) and World Health Organization (WHO) [68] seeks to develop this initiative by:

1. Creating integrated systems of public health and animal health in the long term, and consistent with the International Health Regulations of the World Health Organization and the international standards established by the World Organization for Animal Health.

2. Generating better response capabilities within its members, aimed to prevent regional and international crises caused by epizootic diseases outbreaks.

3. Creating partnerships between developed and developing countries (especially those with low per capita income), to facilitate the transfer of economic resources and knowledge on animal disease control globally.

4. Promoting a multidisciplinary, multinational and cross actions.

5. Developing programs targeted control and eradication of key diseases.

6. Developing strategies to address emerging diseases that involve the private sector in order to build local capacity and strengthen long-term sustainability.

7. Allowing the development of regional, national and international capacity to control TADs through the use of standards, tools and monitoring procedures.

Then the importance of monitoring programs in passive and active wildlife monitoring system, for controlling and preventing of TADs will be exposed by analyzing the situation of a leader and world famous country on conservation (Costa Rica).

\subsection{Case study III: Costa Rica's situation on wildlife transboundary diseases}

Costa Rica has historically been and still is a country that bases its economy in a residual agricultural market. It is, that produces mostly for domestic consumption and exports its surplus. Costa Rica's economy is the $11^{\text {th }}$ largest in Latin America, with a nominal GDP of \$US 34.564 million (2010, $84^{\text {th }}$ place worldwide). The food and livestock industry sectors in Costa Rica are relevant to the national economy, occupying approximately $35 \%$ of the national work force in the pecuary sector and $4.2 \%$ of total employment in the country. The beef and dairy sub-segments constitute both $26 \%$ of the domestic food production. This productive sector occupies (with 14\%), the second place in the composition of the value of its exports in 2008. Nowadays, Costa Rica is now one of only three Latin American countries in dairy surplus, along with Uruguay and Argentina. For example, over 2.2 million liters of milk are produced per day (over 60\% of that volume is processed industrially), exporting over $20 \%$ of the total national production [45].

Costa Rica has only slightly more than $52,000 \mathrm{~km}^{2}$ (about $0.003 \%$ of the global area) and $589,000 \mathrm{~km}^{2}$ of territorial sea, having approximately $4 \%$ of the world total biodiversity [18]. Placing it among the 25 most diverse countries in the world and the first Central American level, although we have only identified about $18 \%$ of our flora and fauna, much of them is endemic (Tables 1 and 2) [49]. However, in Costa Rica there is a marked lack of ex-situ (free 
ranging animals) ecoepidemiological diseases studies from wildlife, even when OIE established in 2007 the need to develop an epidemiological surveillance system in wild animals within its members (Costa Rica is an OIE member since 1993) and the Costarrican National Service for Animal Health (SENASA) has a national program for in-situ (captive animal populations) wildlife health monitoring approach ongoing since 2009. This is very important as the majority of emerging diseases originate in wild animals are concentrated in neotropical developing countries [50]. Therefore, Costa Rica`s richness on biodiversity and its unregulated anthropogenic change on landscape constitute an epidemiological risk for a zoonoses high incidence zone. A list of TADs that may be present in Costa Rica and their respective wild reservoirs was carried out, based on the mandatory OIE animal disease notification's list and the taxonomic basis species of Costa Rica (Atta) running by the National Institute of Biodiversity [48] (Table 3).

\begin{tabular}{|c|c|c|c|c|c|c|}
\hline Group & 1 place & 2 place & 3 place & 4 place & 5 place & $\begin{array}{l}\text { Costa } \\
\text { Rica }\end{array}$ \\
\hline Plants & $\begin{array}{l}\text { Brasil } \\
55000\end{array}$ & $\begin{array}{c}\text { Colombia } \\
50000\end{array}$ & $\begin{array}{l}\text { China } \\
30000\end{array}$ & $\begin{array}{c}\text { Indonesia } \\
27500\end{array}$ & $\begin{array}{c}\text { México } \\
26000\end{array}$ & $\begin{array}{c}\# 11 \text { (11467 } \\
\text { described } \\
\text { species) }\end{array}$ \\
\hline Amphybians & $\begin{array}{c}\text { Colombia } \\
585\end{array}$ & $\begin{array}{c}\text { Brasil } \\
502\end{array}$ & $\begin{array}{c}\text { Ecuador } \\
402\end{array}$ & $\begin{array}{c}\text { Perú } \\
315\end{array}$ & $\begin{array}{c}\text { México } \\
290\end{array}$ & $\begin{array}{c}\# 13 \text { (189 } \\
\text { described } \\
\text { species) }\end{array}$ \\
\hline Reptils & $\begin{array}{c}\text { Australia } \\
867\end{array}$ & $\begin{array}{c}\text { México } \\
704\end{array}$ & $\begin{array}{c}\text { Indonesia } \\
511\end{array}$ & $\begin{array}{c}\text { Colombia } \\
475\end{array}$ & $\begin{array}{c}\text { Brasil } \\
468\end{array}$ & $\begin{array}{c}\# 20 \text { (234 } \\
\text { described } \\
\text { species) }\end{array}$ \\
\hline Mammals & $\begin{array}{c}\text { Indonesia } \\
515\end{array}$ & $\begin{array}{c}\text { México } \\
491\end{array}$ & $\begin{array}{c}\text { Colombia } \\
453\end{array}$ & $\begin{array}{l}\text { USA } \\
428\end{array}$ & $\begin{array}{c}\text { Brasil } \\
421\end{array}$ & $\begin{array}{c}\# 32 \\
\text { (described } \\
\text { species) }\end{array}$ \\
\hline Birds & $\begin{array}{c}\text { Colombia } \\
1753\end{array}$ & $\begin{array}{l}\text { Perú } \\
1678\end{array}$ & $\begin{array}{c}\text { Brasil } \\
1635\end{array}$ & $\begin{array}{c}\text { Ecuador } \\
1559\end{array}$ & $\begin{array}{c}\text { Indonesia } \\
1534\end{array}$ & $\begin{array}{c}\# 24 \text { (864 } \\
\text { described } \\
\text { species) }\end{array}$ \\
\hline
\end{tabular}

Table 1. Species diversity on megadiverse nations and Costa Rica's position.

Source: Taken from [49]

Food security is defined as "A situation that exists when all people, at all times, have physical, social and economic access to sufficient, safe and nutritious food that meets their dietary needs and food preferences for an active and healthy life." [31]. Traditionally, evaluations on animal's disease economic impact have focused on decreasing production costs after a disease outbreak and the subsequent costs associated control and eradication measures. Nowadays is broadly recognized the impact that these diseases have on the international markets for livestock commodities, and the importance of reporting systems in protecting food supplies (food security), international commercial relationships and global trade's fluency [83]. As the impact of TADs is translated into economic losses and costs to production and trade, it's also generate several externalities affecting the differential price between domestic 


\begin{tabular}{lcccc}
\hline \multicolumn{1}{c}{ Group } & $\mathbf{1 9 9 2}$ & $\mathbf{2 0 0 2}$ & $\mathbf{2 0 0 7}$ & $\mathbf{2 0 0 8}$ \\
\hline Virus & 125 & $\mathrm{ND}$ & $\mathrm{ND}$ & $\mathrm{ND}$ \\
Monera & 213 & $\mathrm{ND}$ & $\mathrm{ND}$ & $\mathrm{ND}$ \\
Fungi & 825 & 2311 & 2394 & 3820 \\
Algae & 503 & 564 & $\mathrm{ND}$ & $\mathrm{ND}$ \\
Plantae & 10.000 & 10.353 & 11.451 & 11.453 \\
Protozooa & 670 & $\mathrm{ND}$ & $\mathrm{ND}$ & $\mathrm{ND}$ \\
Nematoda & 85 & 88 & $\mathrm{ND}$ & 182 \\
Mollusca & 1.050 & 1.550 & $\mathrm{ND}$ & $\mathrm{ND}$ \\
Insecta & 65.000 & 66.265 & 66.946 & 68.494 \\
Peces & 916 & 1.080 & $\mathrm{ND}$ & 1.150 \\
Anfibia & 150 & 175 & 183 & 189 \\
Reptiles & 215 & 222 & 226 & 234 \\
Birds & 850 & 854 & 857 & 864 \\
Mammals & 228 & 234 & 237 & 239 \\
\hline
\end{tabular}

Table 2. Species diversity per taxonomic group in de Costa Rica (period 1992-2009) ND: not determine. Source: Modified from [49].

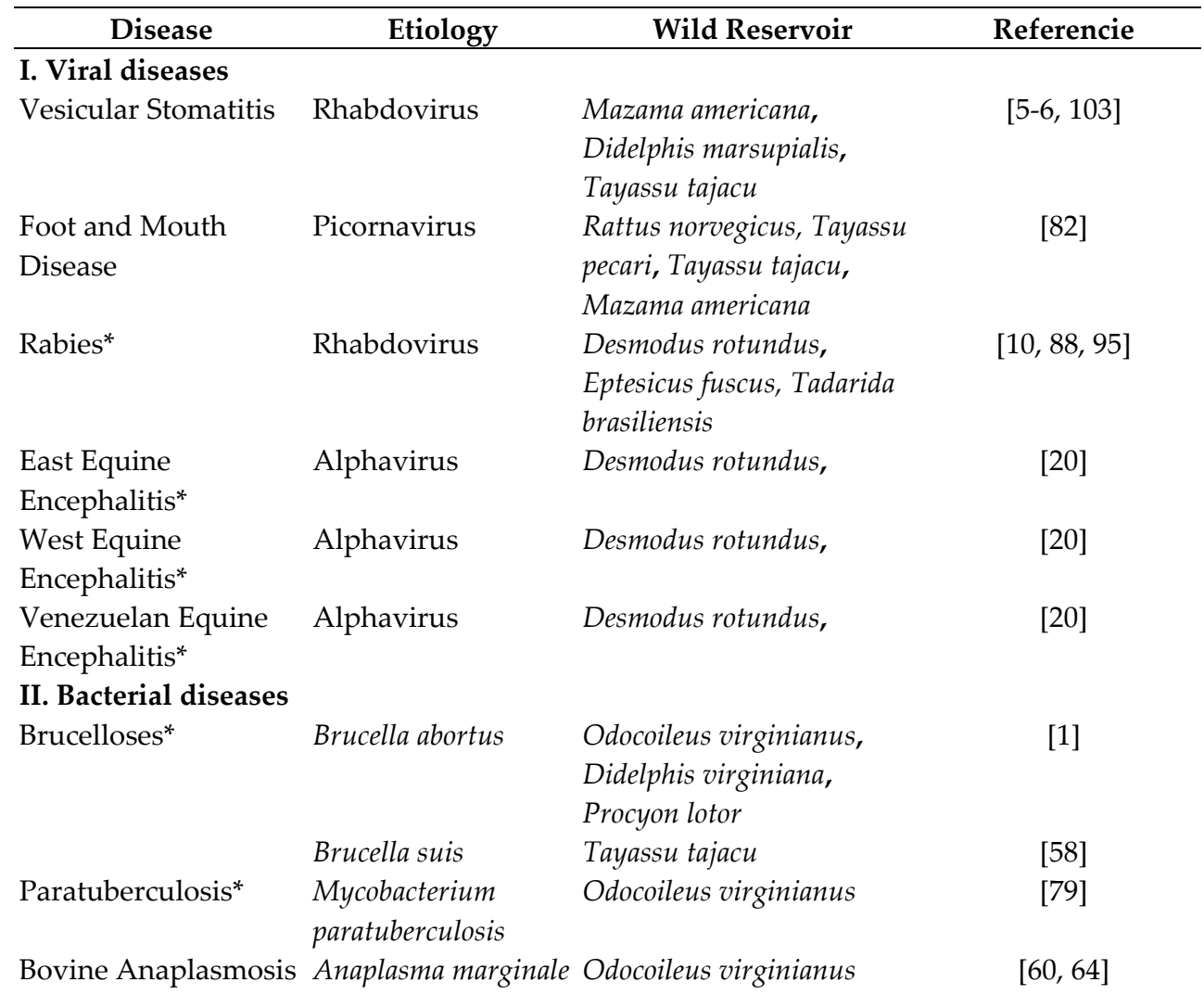




\begin{tabular}{|c|c|c|c|}
\hline Disease & Etiology & Wild Reservoir & Referencie \\
\hline \multirow[t]{2}{*}{ Bovine Babesiosis } & Babesia bovis & Odocoileus virginianus & [16] \\
\hline & Babesia bigemina & Odocoileus virginianus & [16] \\
\hline Bovine Tuberculosis * & $\begin{array}{l}\text { Mycobacterium } \\
\text { tuberculosis }\end{array}$ & Odocoileus virginianus & [59] \\
\hline Leptospirosis* & Leptospira spp. & $\begin{array}{l}\text { Tayassu tajacu, Canis } \\
\text { latrans, Didelphis } \\
\text { marsupialis, Rattus } \\
\text { norvegicus, Tayassu pecari }\end{array}$ & {$[21,37,92,99]$} \\
\hline \multicolumn{4}{|l|}{ III. Parasitic diseases } \\
\hline Hydatidosis* & $\begin{array}{l}\text { Echinococcus } \\
\text { granulosus }\end{array}$ & Canis latrans & [28] \\
\hline Dourine & $\begin{array}{l}\text { Trypanosoma } \\
\text { equiperdum }\end{array}$ & Desmodus rotundus & [80] \\
\hline Surra & Trypanosoma evansi & $\begin{array}{l}\text { Desmodus rotundus, } \\
\text { Tayassu pecari, Tayassu } \\
\text { tajacu }\end{array}$ & {$[44,81]$} \\
\hline
\end{tabular}

Table 3. List for OIE obligatory reporting diseases with wildlife reservoirs in Costa Rica

and imported products, with potential important implications for government policy on biosecurity [100], and also limiting the access to basic food items for poorest people. According to the Economic Commission of the United Nations for Latin America and the Caribbean (ECLAC), the poorest stratus in society, face an inflation rate between 3 and 4 points higher than the general inflation rate for the remainder of the population. Thus, only in Latin America during an important episode of TADs and as result of the subsequent food insecurity, more than 26 million people could fall into poverty and extreme poverty could affect more than $17 \%$ of the total Latin America and the Caribbean's population [34]. In Costa Rica, $16.7 \%$ of households are poor, $3.3 \%$ are in extreme poverty, $4 \%$ of the population is malnourished and the poorest households spend more than $40 \%$ of their salaries on food [61]. Thus, infectious diseases play an important role in decreasing food supply globally and nation's economic growth. The imposition of nontariff barriers to Latin American countries like Costa Rica, would force those nations most vulnerable to import their goods as a direct result for the fluctuating food prices, creating a huge economic impact with profound social consequences in terms of food security, especially affecting marginalized social sectors. Additionally, as a direct result for closing international markets to livestock products, countries could present low economic rates, reduced incomes, a rising on internal inflation and therefore increasing also the dependence on commodities imported [73].

The International Organization for Animal Health (OIE) recognizes the improvement of national standards in animal health, should be parallel to the improvement of veterinary services in terms of increasing the capacity of early epidemiological detection, diagnosis and control of TADs [104]. This raises the questions: 
1. If Costa Rica is not fully involved in this topic, can continue a free zone diseases without any idea of the epizootiology and ecoepidemiology of wildlife TADs in their territory?,

2. How Costa Rica can deal with the emergence of infectious diseases that impact and directly involve human-animal health, generating an impact on the domestic livestock sector which constitutes an important percentage for costarrican economy annually?.

\section{Conclusions}

Animal husbandry and secondary production plays a vital role in the economies of developing countries; through providing protein sources, income, employment and foreign exchange. For low income produces, livestock also serve as a store of wealth. Nowadays, several nations worldwide are investing large amounts of money to eradicate and combat animal diseases; due to humans and climate change are creating favorable conditions for the occurrence of animal pests and diseases into new regions, and are also transforming its transmission mechanism, making that developing countries that rely more on stockbreeding are the most vulnerable. Thus, all countries need to know the endemic animal diseases that circulate in its wild populations and have an adequate veterinary infrastructure to enable early detection of a wide range of zoonotic and emerging diseases at the wildlife-domestic animals-human interface $[9,52]$.

In addition, the biggest challenge for developing countries is to implement and develop actions within a comprehensive framework that considers the different roles on pecuary health and all its actors (public and private), facilitating the ability to respond quickly to TADs with adequate official services sustainably, enabling joint actions, elements for an intersectorial planning compensation and an adequately addressing of emerging issues. Therefore, it is vital that countries in addition to generating disease monitoring programs also implement alternative population control mechanisms in these animal species. Due to lethal control (culling or killing animals) is no longer consider an ethical or decent option for mitigate the transmission of TADs (mainly on threatened or endangered animal populations), substitute novel techniques to control and prevent infectious outbreaks with a legal component based on animal welfare such as vaccination, fertility control and strategic contraception should be contemplated.

Considering that the concept of health is inherent to all species on Earth and it provides a unifying principle that sustains life on all levels has a continuing dynamism complex and inextricable interdependence [87], the amalgamation of many sub-disciplines of biology, veterinary and human medicine is critical to understanding multidisciplinary and controlling emerging diseases. Therefore, national public and animal health systems will play a pivotal role to monitor, assess, predict and prevent the movement of TADs in the oncoming decades. 
Undoubtedly, in future developed nations will be involved in moral and ethical decisions on how help to mitigate the effects of TADs on developing countries. One Health Initiative through Conservation Medicine as a medical discipline will become the necessary engine for the integration of various scientific sectors to promote holistic, integrative and multidisciplinary research, becoming an indispensable tool of national public health or animal control and early prevention of TADs [25].

\section{Author details}

Andrés Cartín-Rojas

Department of Small Animal Sciences, School of Veterinary Medicine, University of Florida at Gainesville and White Oak Conservation Center Animal Science Building, Yulee, FL, USA

\section{References}

[1] Acosta-González R, González-Reyes I, Flores-Gutiérrez G (2006) Prevalence of Brucella abortus Antibodies in Equines of a Tropical Region of Mexico. Canadian. j. vet. research. 70: 302-304.

[2] Aguirre A (2009) Essential Veterinary Education in Zoological and Wildlife Medicine: a Global Perspective. Rev. sci. tech. off. int. epiz. 28: 605-610.

[3] Anand S, Hanson K (1997) Disability-adjusted Life Years: a Critical Review. J. health. econom. 16: 685-702.

[4] Arrivillaga J, Caraballo V (2009) Medicina de la Conservación. Rev. biomed. 20: 5567.

[5] Arboleda J, Restrepo G, Wolff M, Uribe J, Bedoya H, Quiroz V, Pérez S, Morales L, Piedrahita I, Zuluaga F, Ossa J (2001) Ecoepidemiología de la Estomatitis Vesicular en un Municipio Cafetero de Antioquia. Rev. cololomb. cien. pec. 14: 20-27.

[6] Beldomenico M (2006) Medicina y Animales Silvestres: El Desafío de las Ciencias Veterinarias en el Siglo XXI. Rev. FAVE-cien. vet. 5: 7-20.

[7] Beldomenico P, Uhart M (2008) Ecoepidemiología de los Virus de Influenza Aviar. Rev FAVE-cienc. vet. 7: 25-40.

[8] Bengis R, Kock R, Fischer J (2002) Infectious Animal Disease: the Wildlife/Livestock Interface. Rev. sci. tech. off. int. epiz. 21: 53-65.

[9] Ben Jebara K (2004) Surveillance, Detection and Response: Managing Emerging Diseases at National and International Levels. Rev. sci. tech. off. int. epiz. 23: 709-715.

[10] Bernardi F, Nadin-Davis S, Wandeler A, Armstrong J, Gomes A, Lima F, Nogueira F, Ito F (2005) Antigenic and Genetic Characterization of Rabies Viruses Isolated from Domestic and Wild Animals of Brazil Identifies the Hoary Fox as a Rabies Reservoir. J. gen. virol. 86:3153-3162.

[11] Breeze R (2006) Technology, Public Policy and Control of Transboundary Livestock Diseases in Our Lifetimes. Rev. sci. tech. off. int. epiz. 25: 271-292. 
[12] Brown C (2004). Emerging Zoonoses and Pathogens of Public Health Significance-an Overview. Rev. sci. tech. off. int. epiz. 23: 435-442.

[13] Brown C (2010) Emerging Diseases: The Global Express. Vet. pathol. 47: 9-14.

[14] Brückner G (2011) Managing the Risks of Disease Transmission through Trade: a Commodities-Based Approach?. Rev. sci. tech. off. int. epiz. 30: 289-296.

[15] Camacho-Escobar M, Pérez-Lara A, Arroyo-Ledezma E, Sánchez-Bernal J, JiménezGalicia E, Marcela M (2009) Guajolotes de Traspatio como Reservorios de Enfermedades de Aves Domésticas y Silvestres en Tres Ecosistemas de la Costa Mexicana. Trop. Subtrop. agroeconomics. 10: 109-115.

[16] Cantu A, Ortega J, García-Vázquez Z, Mosqueda J, Henke E, George E (2009) Epizootiology of Babesia bovis and Babesia bigemina in Free Ranging White-tailed Deer in Northeastern Mexico. J. parasitol. 95: 536-542.

[17] Cardiff R, Ward J, Barthold S (2008) One Medicine-One Pathology': are Veterinary and Human Pathology Prepared?. Lab. invest. 88: 18-26.

[18] Chen S (2005) Turismo y Ambiente: Un Potencial para el Desarrollo Económico de Costa Rica. Rev. reflex. 84: 25-37.

[19] Chomel B, Belotto A, Meslin F (2007) Wildlife, Exotic Pets, and Emerging Zoonoses. Emerg. infect. dis. 13: 6-11.

[20] Constantine D (2003) Geographic Translocation of Bats: Known and Potential Problems. Emerg. infec. dis. 9: 17-21.

[21] Corn J, Lee R, Erickson G, Murphy C (1987) Serologic Survey for Evidence of Exposure to Vesicular Stomatitis Virus, Pseudorabies Virus, Brucellosis and Leptospirosis in Collared Peccaries from Arizona. J. wildlife dis. 23: 551-557.

[22] Cutler S, Fooks A, Van der Poel W (2010) Public Health Threat of New, Reemerging, and Neglected Zoonoses in the Industrialized World. Emerg. infect. dis. 16: 1-7.

[23] Dabanch J (2003) Zoonosis. Rev. chil. infectol. 20: 47-51.

[24] Daszak P, Cunningham A, Hyatt A (2001) Anthropogenic Environmental Change and the Emergence of Infectious Diseases in Wildlife. Act. trop. 78:103-116.

[25] Daszak P, Tabor G, Kilpatrick M, Epstein J, Plowright R (2004) Conservation Medicine and a New Agenda for Emerging Diseases. Annals. n. y. acad. scien. 1026: 1-11.

[26] Daszack P, Epstein J, Kilpatrick A, Aguirre A, Karesh W, Cunningham A (2007) Collaborative Research Approaches to the Role of Wildlife in Zoonotic Diseases Emergence. Current. top. microbiol. inmunol. 315: 463-475.

[27] Delgado C (2003) Rising Consumption of Meat and Milk in Developing Countries has created a New Food Revolution. J. nutrition. 133: 3907-3910.

[28] Eckert J, Deplazes P (2004) Biological, Epidemiological, and Clinical Aspects of Echinococcosis, a Zoonosis of Increasing Concern. Clin. microbiol rev. 17: 107135.

[29] Elbers A (2002) Local and Global Impact of Disease Outbreaks. Advan. pork. product. 13: $17-27$. 
[30] FAO. Animal Production and Health Commission of FAO (2002) Manual on the Diagnosis of Nipah Virus Infection in Animals. Rome: FAO. 90 p.

[31] FAO. Economic and Social Department of FAO (2003) Trade Reforms and Food Security. Conceptualizing Linkages. Rome: FAO. 315 p.

[32] FAO. Food and Agriculture Organization of the United Nations and World Organization for Animal Health (2004) The Global Framework for the Progressive Control of Transboundary Animal Diseases (GF-TADs). Rome: FAO. 40 p.

[33] FAO. Natural Resources Management and Environment Department of FAO. ClimateRelated Transboundary Pest and Diseases. Technical Background from the Expert Consultation (2008a). Rome: FAO. 59 p.

[34] FAO. Iniciativa América Latina y Caribe Sin Hambre, a través del Observatorio Regional de Seguridad Alimentaria y Nutricional (2008b). Panorama del hambre en América Latina y el Caribe. Roma: FAO. 64 p.

[35] FAO. Agriculture and Consumer Protection Department of FAO (2009) Livestock's Long Shadow: Environmental Issues and Options. Rome: FAO. 493 p.

[36] Fauci A, Touchette N, Folkers G (2005) Emerging Infectious Diseases: A 10-Year Perspective from the National Institute of Allergy and Infectious Diseases. Emerg. infect. dis. 11: 519-525.

[37] Gese E, Schultz R, Johnson M, Williams E, Crabtree R, Ruff R (1997). Serological Survey for Diseases in Free-Ranging Coyotes (Canis Latrans) in Yellowstone National Park, Wyoming. J. wild. dis. 33: 47-56.

[38] González A (2003) Las Enfermedades Virales Emergentes de los Cerdos. Cienc. vet. 9: 197-227.

[39] Greger M (2007) The Human/Animal Interface: Emergence and Resurgence of Zoonotic Infectious Diseases. Crit. rev. microbiol. 33: 243-299.

[40] Hafi A, Reynolds R, Oliver M (1994) Economic Impact of Newcastle Disease on the Australian Poultry Industry. Canberra: Australian Bureau of Agricultural and Resources Economics. 77 p.

[41] Hallet L (2003) Les modes de collaboration entre vétérinaires officiels, vétérinaires privés et organisations d'éleveurs. Rev. sci. tech. off. int. epiz. 22: 523-532.

[42] Heath S (2006) Challenges and Options for Animal and Public Health Services in the Next Two Decade. Rev. sci. tech. off. int. epiz. 25: 403-419.

[43] Herbold J (2005) Emerging Zoonotic Diseases: An Opportunity to Apply the Concepts of Nidality and One-Medicine. Enviro. Health. Prevent. med. 10: 260-262.

[44] Herrera H, Abreu G, Keuroghlian A, Freitas P, Jansen M (2008) The Role Played by Sympatric Collared peccary (Tayassu tajacu), White-lipped Peccary (Tayassu pecari), and Feral Pig (Sus scrofa) as Maintenance Hosts for Trypanosoma evansi and Trypanosoma cruzi in a Sylvatic Area of Brazil. Parasitol. res. 103: 619-24.

[45] Hidalgo-Nuchera A, Herrera-González R, López-Rodríguez V, Velásquez-López G. (2009) El Sector de la Industria Alimenticia de Costa Rica: Una Perspectiva desde la Cadena de Valor. San José: Editorial Universidad de Costa Rica. 315 p. 
[46] Horst S, Huirne R, DLikhuizen A (1997) Risks and Economic Consequences of Introducing Classical Swine Fever into the Netherlands by Feeding Swill to Swine. Rev. sci. tech. off. int. epiz. 16: 207-214.

[47] Horst S, de Vos C, Tomassen F, Stelwagen J (1999) The Economic Evaluation of Control and Eradication of Epidemic Livestock Diseases. Rev. sci. tech. off. int. epiz. 18: 367-379.

[48] INBio, 2012a. Instituto Nacional de Biodiversidad de Costa Rica. Atta (Base de datos de biodiversidad).

http://darnis.inbio.ac.cr/ubisen/FMPro?-DB=UBIpub.fp3\&-lay=WebAll\&error=norec.html\&-Format=default2.htm\&-SortField=nombre\%20cientifico\&Op=eq\&nueva=S\&-Max=3\&-Find. (Acceded 26-may-2012).

[49] INBio, 2012b. Instituto Nacional de Biodiversidad de Costa Rica: http://www.inbio.ac.cr/en/default.html (Acceded 23-may-2012).

[50] Jones E, Patel N, Levy M, Storeygard A, Balk D, Gittleman J, Daszak P (2008) Global Trends in Emerging Infectious Diseases. Nature. 451: 990-994.

[51] Kahn L, Kaplan B, Steele J (2007) Confronting Zoonosis through Collaboration between Medicine and Veterinary Medicine. Vet Italia. 43: 5-19.

[52] King L, Marano N, Hughes J (2004) Between New Animal Health Partnerships and Public Health Services Agencies. Rev. sci. tech. off. int. epiz. 23: 717-726.

[53] King L, Anderson L, Blackmore C, Blackwell M, Lautner E, Marcus L, Meyer T, Monath T, Nave J, Ohle J, Pappaioanou M, Sobota J, Stokes W, Davis R, Glasser J, Mahr R (2008) Executive summary of the AVMA One Health Initiative Task Force report. J. american. vet. med. assoc. 233: 259-260.

[54] Kruse H, Kirkemo A, Handeland K (2004) Wildlife as Source of Zoonotic Infections. Emerg. infect. dis. 10: 2067-2072.

[55] Lam S (2003) Nipah Virus-a Potential Agent of Bioterrorism?. Ant.res. 57: 113119.

[56] La Val R, Rodríguez R (2002) Murciélagos de Costa Rica.Heredia: Editorial Instituto Nacional de Biodiversidad. 320 p.

[57] Li Y, Wang J, Hickey A, Zhang Y, Li Y, Wu Y, Zhang H, Yuan J, Han Z, McEachern J, Broder C, Wang L, Shi Z (2008) Antibodies to Nipah or Nipah-like Viruses in Bats, China. Emerg. infect. diseases. 14: 1974-1976.

[58] Lord V, Lord R (1991) Brucella suis Infections in Collared Peccaries in Venezuela. J. wild. dis. 27: 477-481.

[59] Lyashchenko K, Greenwald R, Esfandiari J, Chambers M, Vicente J, Gortazar C, Santos N, Correia-Neves M, Buddle B, Jackson R, O'Brien D, Schmitt S, Palmer M, Delahay R, Waters W (2008) Animal-side Serologic Assay for Rapid Detection of Mycobacterium bovis Infection in Multiple Species of Free-ranging Wildlife. Vet. microbiol. 132: 283-292.

[60] Maas J, Buening G, Porta W (1981) Serologic Evidence of Anaplasma marginale Infection in White-tailed Deer (Odocoileus virginianus) in Missouri. J. wild. dis. 17: 45-47. 
[61] MEIC. Instituto Nacional de Estadística y Censos (ENIGH) del Ministerio de Economía, Industria y Comercio (2006) Encuesta Nacional de Ingresos y Gastos de los Hogares 2004. Principales resultados. San José: ENIGHP. 259 p.

[62] Morens M, Folkers G, Fauci A (2004). The Challenge of Emerging and Re-emerging Infectious Diseases. Nature. 430: 242-249

[63] Morgan N, Prakash A (2006) International Livestock Markets and the Impact of Animal Disease. Rev. sci. tech. off. int. epiz. 25: 517-528.

[64] Morley R, Hugh-Jones M (1989) Seroepidemiology of Anaplasma marginale in Whitetailed Deer (Odocoileus virginianus) from Louisiana. J. wild. dis. 25: 342-346.

[65] Morner T, Obendorf D, Artois M, Woodford M (2002) Surveillance and Monitoring of Wildlife Diseases. Rev. sci. tech. off. int. epiz. 21: 67-76.

[66] Morse S (2004) Factors and Determinants of Emerging Disease. Rev. sci. tech. off. int. epiz 23: 443-451.

[67] Okello A, Paul E, Gibbs J, Vandersmissen A, Welburn S (2011) One Health and the Neglected Zoonoses: Turning Rhetoric into Reality. Vet Record. 169: 281-285.

[68] OIE, FAO, WHO, UNICEF, WB (2008). A Contribution to "One World, One Health", a Strategic Framework to Reduce Risks of Infectious Diseases at the Animal-HumanEcosystem Interface. Paris: OIE. 68 p.

[69] OIE Terrestrial Code, version 2011: http://www.oie.int/en/international-standardsetting/terrestrial-code/access-online/ (Acceded 23-may-2012).

[70] Olival J, Daszak P (2005). Reviews in NeuroVirology: Emerging Infectious Diseases the Ecology of Emerging Neurotropic Viruses. J. neurovirol, 11: 440-445.

[71] Osburn B, Scott C, Gibbs P (2009) One World - One Medicine - One Health: Emerging Veterinary Challenges and Opportunities. Rev. sci. tech. off. int. epiz. 28: 481-486.

[72] Osofsky S, Cleaveland S, Karesh W, Kock M, Nyhus P, Star L, Yang A (2003) Conservation and Development Interventions at the Wildlife/Livestock Interface. Implications for Wildlife, Livestock and Human Cambridge: IUCN Publications Services Unit. 241 p.

[73] Otte M, Nugent N, McLeod A (2004) Transboundary Animal Diseases: Assessment of Socio-Economic Impacts and Institutional Responses. Rome: FAO. 46 p.

[74] Patz A, Daszak P, Tabor M, Aguirre A, Pearl M, Epstein J, Wolfe D, Kilpatrick A, Foufopoulos J, Molyneux D, Bradley J (2004) Unhealthy Landscapes: Policy Recommendations on Land Use Change and Infectious Disease Emergence. Environment. health. perspect. 112: 1092-1098.

[75] Prat N, Falconi C (2006) Impacto Económico Potencial de la Influenza Aviar en el Sector Avícola de América Latina y el Caribe. Washington: Banco Interamericano de Desarrollo, Serie de informes técnicos del Departamento de Desarrollo Sostenible. 88 p.

[76] Perry B, Grace D (2009) The Impacts of Livestock Diseases and their Control on Growth and Development Processes that are Pro-Poor. Phil. trans. r. soc. b. 364: 26432655. 
[77] Pike B, Saylors K, Fair J, LeBreton M, Tamoufe U. Djoko C, Rimoin A, Wolfe N (2010) The Origin and Prevention of Pandemics. Clin. infect. dis. 50: 1636-1640.

[78] Quesada G (2006) Reporte Final: Aves Acuáticas en Costa Rica. San José: Departamento de Historia Natural, Museo Nacional de Costa Rica. 77 p.

[79] Quist C, Nettles V, Manning E, Hall D, Gaydos K, Wilmers J, Lopez R (2002) Paratuberculosis in Key Deer (Odocoileus virginianus clavium). J. wild. dis. 38: 729737.

[80] Rodrigues A, Fighera R, Souza T, Schild A, Soares M, Milano J, Barros C (2005) Surtos de tripanossomíase por Trypanosoma evansi em eqüinos no Rio Grande do Sul: Aspectos Epidemiológicos, Clínicos, Hematológicos e Patológicos. Pes. vet. bras. 25:239-249.

[81] Rojas A (2005) Desmodus rotundus (Chiroptera: Phyllostomidae) Reservorio y Vector Mecánico de Trypanosoma evansi y T. equiperdum en América Latina. Rev. asoc. vet. v. sil. 1: $10-13$.

[82] Rosenberg F (1975) El Conocimiento de la Epidemiología de la Fiebre Aftosa con Particular Referencia Sudamérica. Rio de Jainero: OPS. 55 p.

[83] Rushton J, Upton M (2006) Investment in Preventing and Preparing for Biological Emergencies and Disasters: Social and Economic Costs of Disasters versus Costs of Surveillance and Response Preparedness. Rev. sci. tech. off. int. epiz. 25: 375-388.

[84] Rhyan J, Spraker T (2010) Emergence of Diseases from Wildlife Reservoirs. Vet. pathol. 47: 34-39.

[85] Salles-Almeida J (2006a) La Aplicación de la Regionalización al Comercio de Carnes: ¿A qué Obedece la Reticencia?. Bol. FAL. 241: 1-4.

[86] Salles-Almeida J (2006b) Gripe Aviar: los Impactos Comerciales de las Barreras Sanitarias y los Desafíos para América Latina y el Caribe. Chile: CEPAL-ONU. 55 p.

[87] Santisteban F (2007) Zoonosis Emergentes: Un Reto Interdisciplinar. Gacet. med. bilbao. 107: 7-10.

[88] Schneider M, Romijn P, Uieda W, Tamayo H, Fernandes D, Belotto A, Barbosa J, Leanes L (2009) Rabies Transmitted by Vampire Bats to Humans: An Emerging Zoonotic Disease in Latin America?. Pan. american. j. publ. h. 25: 260-269.

[89] Sherman D (2010) A Global Veterinary Medical Perspective on the Concept of One Health: Focus on Livestock. ILAR. j. 51: 281-287.

[90] Slenning B (2010) Global Climate Change and Implications for Disease Emergence. Vet. pathol. 47: 28-33.

[91] Tabor G (2002) Defining Conservation Medicine. In: Aguirre A, Ostfeld R, Tabor G, Haouse C, Pearl M, editors. Conservation Medicine. New York: Oxford University Press. 407 p.

[92] Tavares T, Keuroghlian A, Eaton D, de Freitas E, Figueiredo A, Nakazato L, de Oliveira J, Miranda F, Paes R, Monteiro L, Lima J, Neto A, Dutra V, de Freitas J (2010) Prevalence of Leptospira interrogans Antibodies in Free-ranging Tayassu pecari of the Southern 
Pantanal, Brazil, an Ecosystem where Wildlife and Cattle Interact. Trop. animal. h. prod. 42: 1695-1703.

[93] Tey S, Suryani D, Emmy F, Illisriyan I (2009) Food Consumption and Expenditures in Singapore: Implications to Malaysia's Agricultural Exports. internt. f. res. j. 16: 119126.

[94] Thierman A (2004) Emerging Diseases and Implications for Global Trade. Rev. sci. tech. off. int. epiz. 23: 701-708.

[95] Trimarchi C, Debbie J (1977) Naturally Occurring Rabies Virus and Neutralizing Antibody in Two Species of Insectivorous Bats of New York state. J. wild. dis. 13: 366369.

[96] Vallat. B, Mallet E (2006) Ensuring Good Governance to Address Emerging and Reemerging Animal Diseases Threat: Supporting the Veterinary Services of Developing Countries to Meet OIE International Standards and Quality. Rev. sci. tech. off. int. epiz. 25: 389-401.

[97] Vallat B, Pinto J, Schudel A (2006) International Organizations and their Role in Helping to Protect the Worldwide Community against Natural and Intentional Biological Disasters. Rev. sci. tech. off. int. epiz. 25: 163-172.

[98] Vandeputte S, Humblet M, Fecher-Bourgeois F, Gosset C, Albert A, Vernaillen F, Saegerman C (2011) Instruments de Gestion Économique des Crises Sanitaires Touchant les Animaux de Production en Europe. Rev. sci. tech. off. int. epiz. 30: 683-701.

[99] Vieira A (2009) Levantamento de Leptospira spp. en Animais Silvestres do Pantanal SulMatto-Grosense, por Meio de Técnicasa Sorologicas e Moleculares. Brazil: Universidade Federal de Matto Grosso do Sul. 83 p.

[100] Waage J, Mumford J (2008) Agricultural Biosecurity. Phil. trans. r. soc. b. 363: 863876.

[101] Walker W (1998) Taller sobre Inocuidad de los Alimentos en el Comercio Agropecuario Internacional. México, D.F: Instituto Interamericano de Cooperación para la Agricultura (IICA) 9 p.

[102] Wilson T, Logan-Henfrey L, Weller R, Kellman B (2000) Agroterrorism, Biological Crimes, and Biological Warfare Targeting Animal Agriculture. In: Brown C, Bolin C editors. Emerging Diseases of Animals. Washington: ASM Press. 310 p.

[103] Wilson A, Araínga M, Gálvez H, Manchego A, Rivera H (2005) Anticuerpos Contra el Virus de la Estomatitis Vesicular en Sajinos (Tayassu tajacu) de Zoocriaderos de Iquitos y Pucallpa. Rev. invest. vet. Perú. 16: 180-183.

[104] Woodford J (2004) Synergies between Veterinarians and Para-professionals in the Public and Private Sectors: Organizational and Institutional Relationships that Facilitate the Process of Privatizing Animal Health Services in Developing Countries. Rev. sci. tech. off. int. epiz. 23: 115-135.

[105] Yaiw K, Bingham J, Crameri G, Mungall B, Hyatt A, Yu M, Eaton B, Shamala D, Wang L, Thong K. 2008. Tioman Virus, a Paramyxovirus of Bat Origin, Causes Mild Disease in Pigs and has a Predilection for Lymphoid Tissues. J. virol. 82: 565-568. 
[106] Zhu H, Chu D, Liu W, Dong B, Zhan S, Zhang J, Li L, Vijaykrishna D, Smith G, Chen H, Poon L, Peiris J, Guan Y (2009) Detection of Diverse Astroviruses from Bats in China. J. gen. virol. 90: 883-887. 